\title{
Aeromagnetic survey in south-eastern Greenland: project Aeromag 2013
}

\author{
Peter Riisager and Thorkild M. Rasmussen
}

Aeromagnetic surveys are nowadays used at a wide range of scales and purposes. In frontier and under-explored areas, where data are otherwise sparse or non-existent, aeromagnetic acquisition remains the cheapest and easiest way to obtain or refine a picture of the structural setting. Aeromagnetic data are also useful for strategic planning of geological mapping campaigns and detailed geophysical data acquisition. Moreover, aeromagnetic data are of importance for prospecting, helping to define prospects. Large aeromagnetic surveys can be carried out efficiently and safely almost everywhere, in a short period of time and at reasonable cost.

In the following we present the newly released Aeromag 2013 aeromagnetic survey that covers a remote and relatively under-explored coastal region in south-eastern Greenland, stretching from $64^{\circ} 45^{\prime} \mathrm{N}$ and northward to $67^{\circ} 30^{\prime} \mathrm{N}$ (Fig. 1). The survey represents a total of 65492 line $\mathrm{km}$, and covers an area of $30100 \mathrm{~km}^{2}$, adding a significant new dataset to the already existing database of government-financed geophysical surveys in Greenland. With the completion of the Aeromag 2013 project, the database presently contains a total of $c .633500$ line $\mathrm{km}$ of high-resolution aeromagnetic data and $c .75000$ line $\mathrm{km}$ of multi-parameter data (electromagnetic, magnetic and partly radiometric data). Further details on previous surveys on Greenland and the database of available aeromagnetic data are summarised in Rasmussen et al. (2013; see also Fig. 1).

\section{Details of the Aeromag 2013 survey}

EON Geosciences Inc. flew the Aeromag 2013 survey between 13 June and 2 September 2013, using two Piper Navajo PA-31 aircraft equipped with geophysical instruments (detailed below), and operating out of the airport at Kulusuk. The magnetic base stations used for correction of diurnal magnetic variations were installed at two different locations in Kulusuk.

The survey was carried out by flying along a gently draped surface $300 \mathrm{~m}$ above the ground or sea level. Due to the severe topography ranging from sea level to $c .2450 \mathrm{~m}$, the gentle drape resulted in an average height above ground of $711 \mathrm{~m}$. The survey lines were NE-SW-oriented, parallel to the coastline with a separation of $500 \mathrm{~m}$ while orthogonal tie-lines were flown with a separation of $5000 \mathrm{~m}$. Total magnetic field data were recorded with a sampling interval of 0.1 sec. which corresponds to a sample distance of $c .7 \mathrm{~m}$. The magnetic field at the base station was recorded with a $1 \mathrm{sec}$. sampling interval. Aircraft positional data from differential GPS measurements were recorded with a $1 \mathrm{sec}$. sampling interval, and aircraft altitude measurements obtained from barometric altimeter and radar were recorded with a sampling interval of $0.1 \mathrm{sec}$. A continuous digital video recording of the terrain passing below was also produced. Further details on the survey operation and equipment can be found in a report by EON Geosciences Inc. (2013), which is available at the online DODEX database at the Geological Survey of Denmark and Greenland (Riisager et al. 2011).

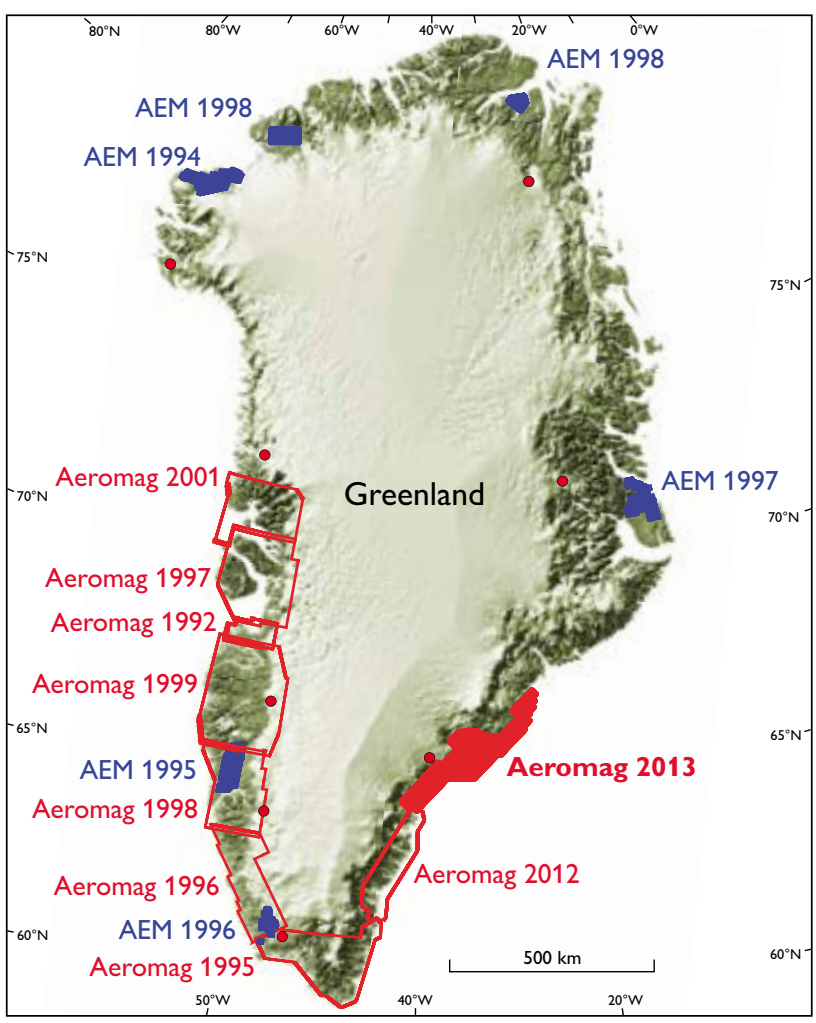

Fig. 1. Map of Greenland showing the location of government-financed high-resolution airborne geophysical surveys conducted from 1992 to 2014. Red: aeromagnetic surveys (Aeromag). Blue: combined electromagnetic and magnetic surveys (AEM). 


\section{Results and products}

The Aeromag 2013 survey dataset can be obtained as line data in the format of a Geosoft database. In addition two map sheets at scales of 1:250 000 and 35 map sheets at scales of 1:50 000 have been produced from interpolation and gridding of the data. The map sheets are available as both grid-files and pdf-files. Each of the map sheets shows the total magnetic field intensity and first and second vertical derivatives. Figure 2 shows the gridded total magnetic field intensity data for the entire survey area. The International Geomagnetic Reference Field corresponding to the date and location of the measurement has been subtracted from the data leaving the magnetic anomalies caused by the variation of magnetisation in the uppermost crust. Superimposed on the magnetic anomaly data in Fig. 2 is a shaded relief modelled by using a light-source illumination inclination of $45^{\circ}$ and a declination of $45^{\circ}$ (i.e. a light-source from the northwest).

\section{Release of data}

The completion of the Aeromag 2013 project was marked by the release of the data on 3 March 2014. The data can be obtained for free from the Ministry of Industry and Mineral Resources in Greenland by submitting a form available at the Greenland Mineral Resources portal ( $h t t p: / / w w w$. greenmin.gl/).

\section{Magnetic anomaly maps and geological implications}

The surface geology of the surveyed region is shown on the map in Fig. 3. The survey covers the eastern part of the Nagssugtoqidian orogen that mainly consists of reworked Archaean gneisses with minor supracrustal rocks and several Palaeoproterozoic intrusives (Bridgwater et al. 1990; Kolb in press). Palaeogene intrusions and coast-parallel dykes are found in the northern part of the survey area (Tegner $e t$ al. 1998).

The magnetic anomalies mapped in the Aeromag 2013 survey area range in amplitudes between $-1318 \mathrm{nT}$ and $+3270 \mathrm{nT}$, with both the most negative and positive values relating to mapped intrusions (Figs 2, 3). In the southern part of the survey area, several NNE-SSW-trending subparallel linear and positive anomalies (marked I in Fig. 2) are clearly discernible, and most likely represent large dykes. The anomalies can be traced in the survey area over more than

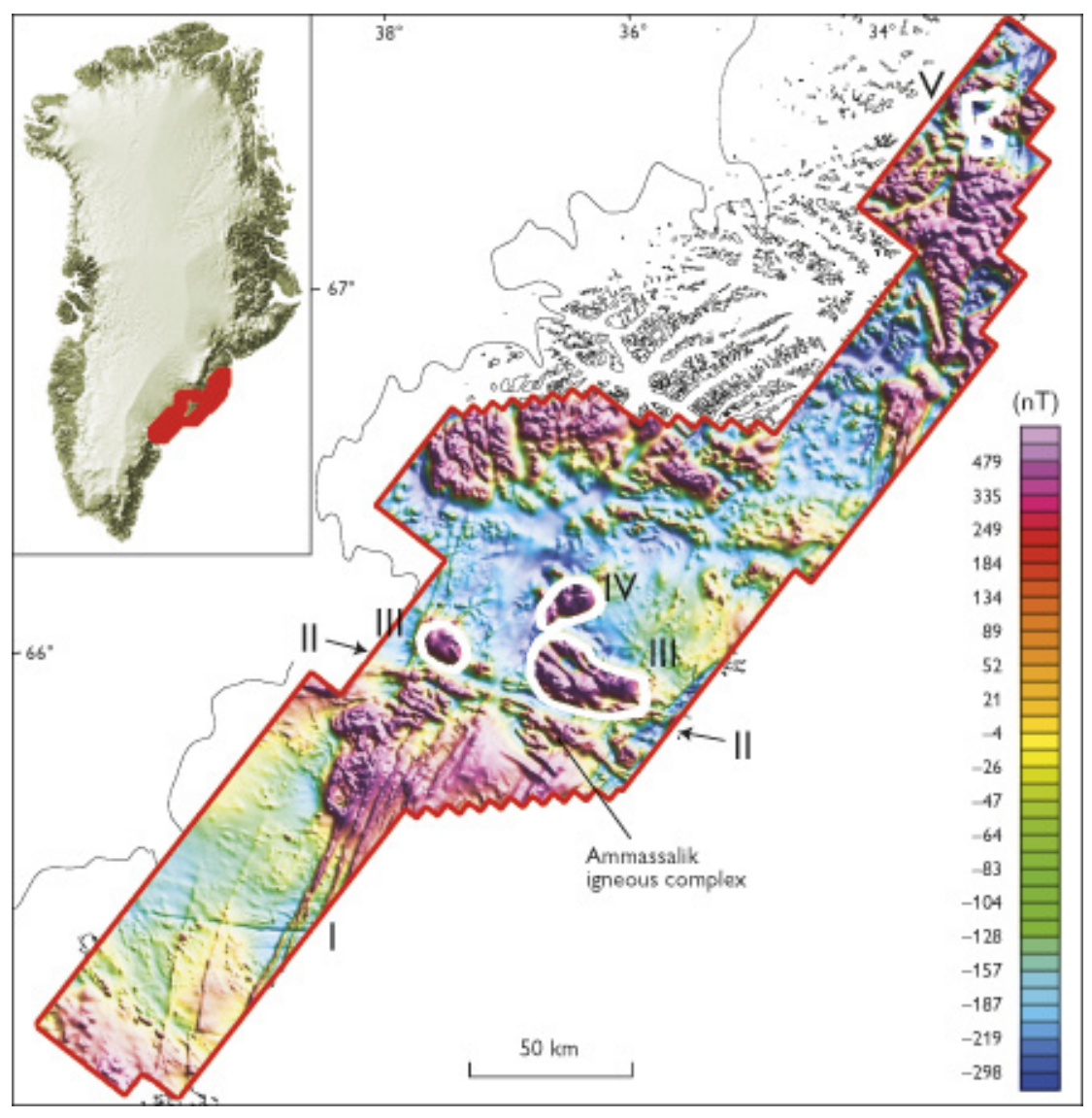

Fig. 2. Aeromagnetic anomaly map of the survey area in south-eastern Greenland covered during the Aeromag 2013 project. I-V: magnetic anomalies discussed in the text. I: Possible large dykes NNE-SSW. II: Magnetic E-W low. III: Ammassalik igneous complex. IV: 1.9-2.2 Ga diorite intrusion. V: Kruse Fjord gabbro complex. 
Fig. 3. Geological map of the survey area in south-eastern Greenland (modified from Escher 1990). Red: the Aeromag 2013 survey area. I-V: magnetic anomalies discussed in the text.

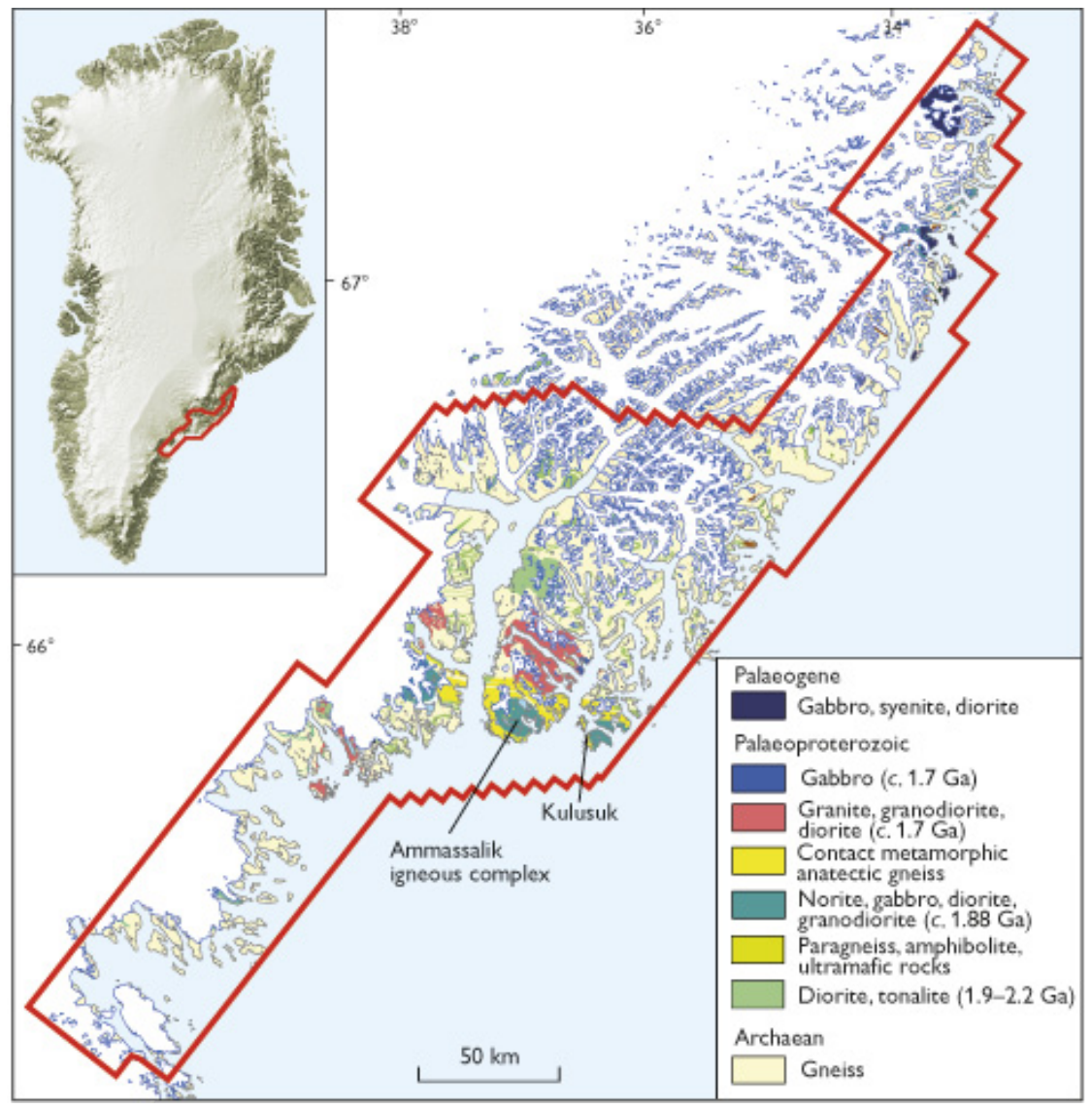

$120 \mathrm{~km}$ and presumably extend offshore. To the north, several of these anomalies appear to be truncated by a magnetic low (II; Fig. 2) just north of the Ammassalik igneous complex. The magnetic anomalies measure $1-2 \mathrm{~km}$ across and have amplitudes in the order of $300 \mathrm{nT}$, with a magnetisation direction enhancing the present geomagnetic field suggesting a magnetisation dominated by induced magnetisation or a remanent magnetisation with a direction in the same general direction as the present geomagnetic field or both. The linear magnetic anomalies, which are mainly found offshore, are both much larger, and have a different orientation than the ENE-WSW-striking mafic dykes mapped in the area (Bridgwater et al. 1990). In order to estimate the depth of the source of the magnetic anomalies, Euler deconvolution (Reid et al. 1990) was carried out using the Standard Euler 3D method of the Geosoft package software v. 8.1. The method is based on Euler's homogeneity equation that relates the magnetic field and its gradient components to the location of the source. The system uses a least squares method to solve Euler's equation simultaneously for each grid position within a window and then determines the anomaly position, depth, and base level for a specific magnetic source. The most critical parameter in the Euler deconvolution is the structural index, which enters as an exponential factor corresponding to the rate at which the field falls off with distance, for a source of a given geometry. For our analysis we used a structural index value of 1 , which is suitable for a dyke, and a window size of 2 $\mathrm{km}$. The resulting depth estimates for the top of the dykes are generally below $400 \mathrm{~m}$. Given the uncertainty of the depth estimates, and the up to $200 \mathrm{~m}$ water depth in the offshore area (Becker et al. 2009) where the magnetic anomalies are best defined, it is possible that the dykes are exposed near the coast. Finally, we note that the Kangâmiut dykes found in West Greenland, in a similar location on the North Atlantic craton (south of the central part of the Nagssugtoqidian orogen in West Greenland) are much less prominent magnetically (Rasmussen \& van Gool 2000; Korstgård et al. 2006) than the linear magnetic anomalies seen in the Aeromag 2013 survey area. We tentatively interpret the linear magnetic anomalies as massive dykes.

The E-W-trending magnetic low just north of the Ammassalik igneous complex marked II in Fig. 2 coincides with a suggested suture zone of the Nagssugtoqidian orogen, where the Rae craton to the north-east in an oblique WSWdirected subduction collided with the North Atlantic craton south of the suture zone at $c .1870-1885 \mathrm{Ma}$ (Kolb in press). The suggested location of the suture zone is also supported by the apparent abrupt termination of several of the positive 
NNE-SSW-trending anomalies marked I on Fig. 2 and discussed above.

North of the Ammassalik igneous complex the $c .1 .7 \mathrm{Ga}$ post-orogenic granodiorite intrusion marked III in Fig. 2 is clearly defined by positive magnetic anomalies with amplitudes up to almost $2000 \mathrm{nT}$. Similarly, the older 1.9-2.2 Ga diorite intrusion farther north marked IV in Fig. 2 is associated with a strong $(c .2500 \mathrm{nT})$ positive magnetic anomaly. The strongest magnetic anomalies in the Aeromag 2013 survey area are found in the northern part of the survey area and can be related to the Palaeogene intrusions in the area. The Kruuse Fjord gabbro complex marked V in Fig. 2 is related to a negative anomaly, hence having a magnetisation dominated by reversely magnetised remanent magnetisation, which is in excellent accordance with an Ar-Ar isochron age of $48.0 \pm$ 1.2 $\mathrm{Ma}$, and emplacement of the intrusive complex during the reverse C21R chron (Cande \& Kent 1995).

\section{Conclusions}

In this paper we present the newly released Aeromag 2013 survey that adds new and exciting data to the already extensive database of Greenland aeromagnetic data. The paper focuses on magnetic anomalies of regional extent, including sub-parallel linear and positive anomalies trending NNESSW (marked I on Fig. 2) that we suggest stem from hitherto undiscovered very large dykes. The suggested location of the suture zone of the Nagssugtoqidian just north of the Ammassalik igneous complex (II; Fig. 2) is supported by the aeromagnetic data. Finally, we note a general good correspondence between the mapped surface geology of the region and the aeromagnetic data; in particular, the intrusions which are clearly discernible. The magnetic data provide a basis for further analysis and modelling of the 3D geometry of the igneous intrusions. Many more local anomalies can be identified in the Aeromag 2013 dataset but interpretations require further analyses.

\section{Acknowledgements}

Funding of the Aeromag 2013 project was provided by the Ministry of Industry and Mineral Resources, Government of Greenland. Thanks are due to EON Geosciences Inc. for fulfilling all aspects of their contracts in a professional manner.

\section{References}

Becker, J.J. et al. 2009: Global bathymetry and elevation data at 30 arc seconds resolution: SRTM30_PLUS. Marine Geodesy 32, 355-371.

Bridgwater, D., Austrheim, H., Hansen, B.T., Mengel, F., Pedersen, S. \& Winter, J. 1990: The Proterozoic Nagssugtoqidian mobile belt of southeast Greenland: a link between the eastern Canadian and Baltic shields. Geoscience Canada 17, 305-310.

Cande, S.C. \& Kent, D.V. 1995: Revised calibration of the geomagnetic polarity timescale for the Late Cretaceous and Cenozoic. Journal of Geophysical Research, Solid Earth 100, 6093-6095.

Eon Geosciences Inc. 2013: Final survey report. High resolution aeromagnetic survey, Southeast Greenland Aeromag 2013 Block, 31 pp. Unpublished report, Eon Geosciences Inc., Montreal, Quebec, Canada (in archives of the Geological Survey of Denmark and Greenland, report File 23712).

Escher, J.C. 1990: Geological map of Greenland, 1:500 000, Sheet 14, Skjoldungen. Copenhagen: Geological Survey of Greenland.

Kolb, J. in press: Structure of the Palaeoproterozoic Nagssugtoqidian Orogen, South-East Greenland: model for the tectonic evolution. Precambrian Research, http://dx.doi.org/10.1016/j.precamres.2013.12.015

Korstgård, J.A., Stensgaard, B.M. \& Rasmussen, T.M. 2006: Magnetic anomalies and metamorphic boundaries in the southern Nagssugtoqidian orogen, West Greenland. Geological Survey of Denmark and Greenland Bulletin 11, 179-184.

Rasmussen, T.M., Thorning, L., Riisager, P. \& Tukiainen T. 2013: Airborne geophysical data from Greenland. Geology and Ore, Exploration and Mining in Greenland. 22, 12 pp.

Rasmussen, T.M \& van Gool, J.A.M. 2000: Aeromagnetic survey in southern West Greenland: project Aeromag 1999. Geology of Greenland Survey Bulletin 186, 73-77.

Reid, A.B., Allsop, J.M., Granser, H., Millett, A.J. \& Somerton, I.W. 1990: Magnetic interpretation in three dimensions using Euler deconvolution. Geophysics 55, 80-90.

Riisager, P., Pedersen, M., Jørgensen, M.S., Schjøth, F. \& Thorning, L. 2011: DODEX - geoscience documents and data for exploration in Greenland. Geological Survey of Denmark and Greenland Bulletin 23, 77-80.

Tegner, C., Duncan, R.A., Bernstein, S., Brooks, C.K., Bird, D.K. \& Storey, M. 1998: ${ }^{40} \mathrm{Ar}-{ }^{39} \mathrm{Ar}$ geochronology of Tertiary mafic intrusions along the East Greenland rifted margin: relation to flood basalts and the Iceland hotspot track. Earth and Planetary Science Letters 156, 75-88.

\section{Authors' address}

Geological Survey of Denmark and Greenland, Øster Voldgade 10, DK-1350 Copenhagen K, Denmark. E-mail:pri@geus.dk. 